\title{
Penetrating keratoplasty in eThekwini Health District 2011-2014
}

\begin{tabular}{|c|c|}
\hline \multicolumn{2}{|c|}{$\begin{array}{l}\text { Authors: } \\
\text { Monawwar Khan }{ }^{1} \\
\text { Linda Visser }^{1} \\
\text { Saajida Mahomed }\end{array}$} \\
\hline \multicolumn{2}{|c|}{$\begin{array}{l}\text { Affiliations: } \\
{ }^{1} \text { Department of } \\
\text { Ophthalmology, Nelson R. } \\
\text { Mandela School of Medicine, } \\
\text { University of KwaZulu-Natal, } \\
\text { South Africa }\end{array}$} \\
\hline \multicolumn{2}{|c|}{$\begin{array}{l}{ }^{2} \text { Department of Public } \\
\text { Health Medicine, Nelson R. } \\
\text { Mandela School of Medicine, } \\
\text { University of KwaZulu-Natal, } \\
\text { South Africa }\end{array}$} \\
\hline \multicolumn{2}{|c|}{$\begin{array}{l}\text { Correspondence to: } \\
\text { Monawwar Khan }\end{array}$} \\
\hline \multicolumn{2}{|c|}{$\begin{array}{l}\text { Email: } \\
\text { mk.light@yahoo.com }\end{array}$} \\
\hline \multicolumn{2}{|c|}{$\begin{array}{l}\text { Postal address: } \\
\text { Private Bag 7, Congella, } \\
\text { Durban 4013, South Africa }\end{array}$} \\
\hline \multicolumn{2}{|c|}{$\begin{array}{l}\text { Dates: } \\
\text { Received: } 22 \text { Feb. } 2015 \\
\text { Accepted: } 22 \text { Apr. } 2015 \\
\text { Published: } 09 \text { July } 2015\end{array}$} \\
\hline \multicolumn{2}{|c|}{$\begin{array}{l}\text { How to cite this article: } \\
\text { Khan M, Visser L, Mahomed } \\
\text { S. Penetrating keratoplasty } \\
\text { in eThekwini Health District } \\
\text { 2011-2014. Afr Vision Eye } \\
\text { Health. 2015;74(1), Art. } \\
\text { \#299, } 4 \text { pages. http://dx.doi. } \\
\text { org/10.4102/aveh.v74i1.299 }\end{array}$} \\
\hline \multicolumn{2}{|c|}{$\begin{array}{l}\text { Copyright: } \\
\text { (C) 2015. The Author(s). } \\
\text { Licensee: AOSIS } \\
\text { OpenJournals. This work is } \\
\text { licensed under the Creative } \\
\text { Commons Attribution } \\
\text { License. }\end{array}$} \\
\hline \multicolumn{2}{|l|}{ Read online: } \\
\hline 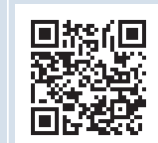 & $\begin{array}{l}\text { Scan this QR } \\
\text { code with your } \\
\text { smart phone or } \\
\text { mobile device } \\
\text { to read online. }\end{array}$ \\
\hline
\end{tabular}

Background: Penetrating keratoplasty (PK - corneal transplantation or full-thickness corneal graft) remains the primary sight-restoring procedure for corneal blindness. South Africa is experiencing a shortage of donor corneas, resulting in long waiting times for a corneal transplant. A corneal graft protocol has been drawn up in the eThekwini Health District to triage prospective corneal graft recipients.

Aim: To describe the clinical and demographic profiles of patients on the elective corneal graft waiting list, the waiting time for PK and the scoring system prioritisation process of corneal graft allocation.

Setting: All patients on the elective corneal graft waiting list in the eThekwini Health District.

Methods: An observational, descriptive cross-sectional study was conducted for a 3-year period between April 2011 and March 2014.

Results: A total of 104 patients were on the elective corneal graft waiting list for PK during the study period. Only $20 \%(n=21)$ of patients received a corneal graft during the 3-year period. Amongst those that received a corneal graft, the median waiting period was 280 days (interquartile range 143-520 days). The majority of patients on the waiting list (67\%) were younger than 41 years of age. The commonest indication for PK was keratoconus (64\%). Patients with higher pro forma scores are more likely to receive a corneal graft when a donor cornea becomes available.

Conclusion: With a shortage of donor corneas, very few patients receive a corneal graft. Educational programmes are vital to increase awareness of corneal blindness and the value of corneal donations.

\section{Introduction}

Corneal blindness is one of the major causes of blindness worldwide. ${ }^{1}$ Globally unilateral corneal blindness is estimated to affect 23 million people and bilateral corneal blindness 4.9 million people..$^{2,3,4}$

Corneal transplantation remains the primary sight-restoring procedure for corneal blindness, and a corneal graft allows many patients to regain vision and become active members of society. ${ }^{5}$ Eye banks are the institutions responsible for collecting (harvesting) and processing donor corneas, and for distributing them to trained corneal graft surgeons. ${ }^{6}$

South Africa (SA) is experiencing a shortage of donor corneas, resulting in long waiting times. Patients wait many years for a corneal transplant.

Due to the shortage of donor corneas an elective corneal graft protocol has been drawn up in the eThekwini Health District, which attempts to justifiably and objectively triage prospective corneal graft recipients. A corneal graft pro forma has been developed to aid in the prioritisation process.

The elective corneal graft waiting list for penetrating keratoplasty (PK - full-thickness corneal graft) in the eThekwini Health District has not previously been studied.

\section{Objectives}

To describe the clinical and demographic profiles of patients on the elective corneal graft waiting list, the waiting time for PK and the scoring system prioritisation process for corneal graft allocation. 


\section{Methods}

An observational, descriptive cross-sectional study was conducted for a 3-year period between 1 April 2011 and 31 March 2014.

The study population included only those patients on the elective corneal graft waiting list at a tertiary academic hospital in Durban. This waiting list includes all patients awaiting a corneal transplant in the public sector in the eThekwini Health District. Demographic and clinical data were collected from patient medical records and the corneal graft pro forma.

Patients who require a corneal graft are assessed and scored on seven criteria: (1) the visual acuity in the eye for grafting, (2) the patient's age, (3) patient's occupation, (4) status of the other eye, (5) pain and discomfort experienced, (6) risk for graft failure and (7) the number of years the patient has been on the waiting list (Figure 1). Points are allocated for each criterion and all patients are then given a score. The highest achievable pro forma score, excluding criterion 7 , is 61 points. Patients with higher scores are better positioned in the prioritisation process and more likely to receive a corneal graft when a donor cornea becomes available.

Descriptive statistics were used to analyse the data. Waiting time was calculated by counting the number of days between the date on which a patient's name was put onto the waiting list and the date on which the patient received the corneal graft.

The study was approved by the Biomedical Research Ethics Committee at the University of KwaZulu-Natal.

\section{Results}

A total of 104 patients were on the elective corneal graft waiting list for PK over the study period. The median patient age was 31 years (interquartile range 22-47 years) (Table 1 ). The majority of patients on the waiting list (67\%) were younger than 41 years of age. The youngest patient was 5 years of age and the oldest 88 years old. There were more females $(59 \%, n=61)$ than males $(41 \%, n=43)$. In keeping with the provincial demographics, the majority of the population were black persons $(64 \%, n=67)$, followed by Indian persons $(32 \%, n=33)$ and white persons $(4 \%, n=4)$.

The commonest indication for putting a patient on the corneal graft waiting list was keratoconus, which accounted for $64 \%$ of the patients (Table 1).

Eighty four per cent $(n=88)$ of patients had a best corrected visual acuity of $6 / 60$ or worse in the eye awaiting a corneal graft.

Only 20\% $(n=21)$ of patients received a corneal graft during the 3-year period. In these patients the median waiting period was 280 days (interquartile range 143-520 days).
Of the patients who received a corneal graft, the highest pro forma score was 52 and the lowest was 28. Most patients $(81 \%, n=17)$ that received a graft had a pro forma score of greater than 40. A scatter plot showing the waiting time and pro forma score of those patients that received a corneal graft during the study period is shown in Figure 2.

Eighty per cent of patients on the waiting list did not receive a corneal graft during the study period.

\section{Discussion}

Blindness from corneal pathology occurs in the economically active population, and in lower-to middle-income countries this blindness occurs in a significantly younger population. ${ }^{7,8}$ In this study the vast majority of patients awaiting a corneal transplant were younger than 41 years of age. This also reflects that corneal diseases affect many in their most productive years, and that the corneal blindness population could have higher disability-adjusted life years. In economic terms the cost of blindness depends not only on the cause and duration of the blinding disease, but also on the availability of family or alternative sources of economic assistance for blind individuals. People blinded at a younger age incur a higher economic cost to their family members and society over their lifetime than adults blinded in later life. ${ }^{9}$

The indications for corneal transplantation vary considerably in different geographical regions and countries. In the past decade many indications for corneal transplantation have been proposed and several novel indications have been reported, including keratoconus, pseudophakic bullous keratopathy, corneal scarring, keratitis, and corneal dystrophies. ${ }^{10}$ The commonest indication for PK in our setting was keratoconus. In a survey amongst ophthalmologists working in the private sector in Johannesburg, keratoconus was also the commonest indication for PK. ${ }^{11}$

In lower- to middle-income countries, where the magnitude of corneal blindness is the greatest, the availability of donated corneas is very low. ${ }^{12}$ This is reflected in the low proportion of patients that received a corneal graft in our setting. Many scholars and economically active patients are therefore unable to function optimally due to long waiting times for a corneal graft. This inadequate supply of donor corneas can be attributed to lack of funding, lack of awareness of both the public and healthcare workers with regard to corneal transplantation, community attitudes, and religious background. ${ }^{11}$

In SA Etheredge ${ }^{13}$ noted that black Africans are more willing to donate kidneys, lungs and heart compared to corneas. This indicates that corneal transplantation is not well understood in some communities, and could partly explain the unwillingness of such communities to donate corneas. ${ }^{11}$ Another important factor is the impact of State legislation regarding organ donation. SA has an opt-in system of organ 


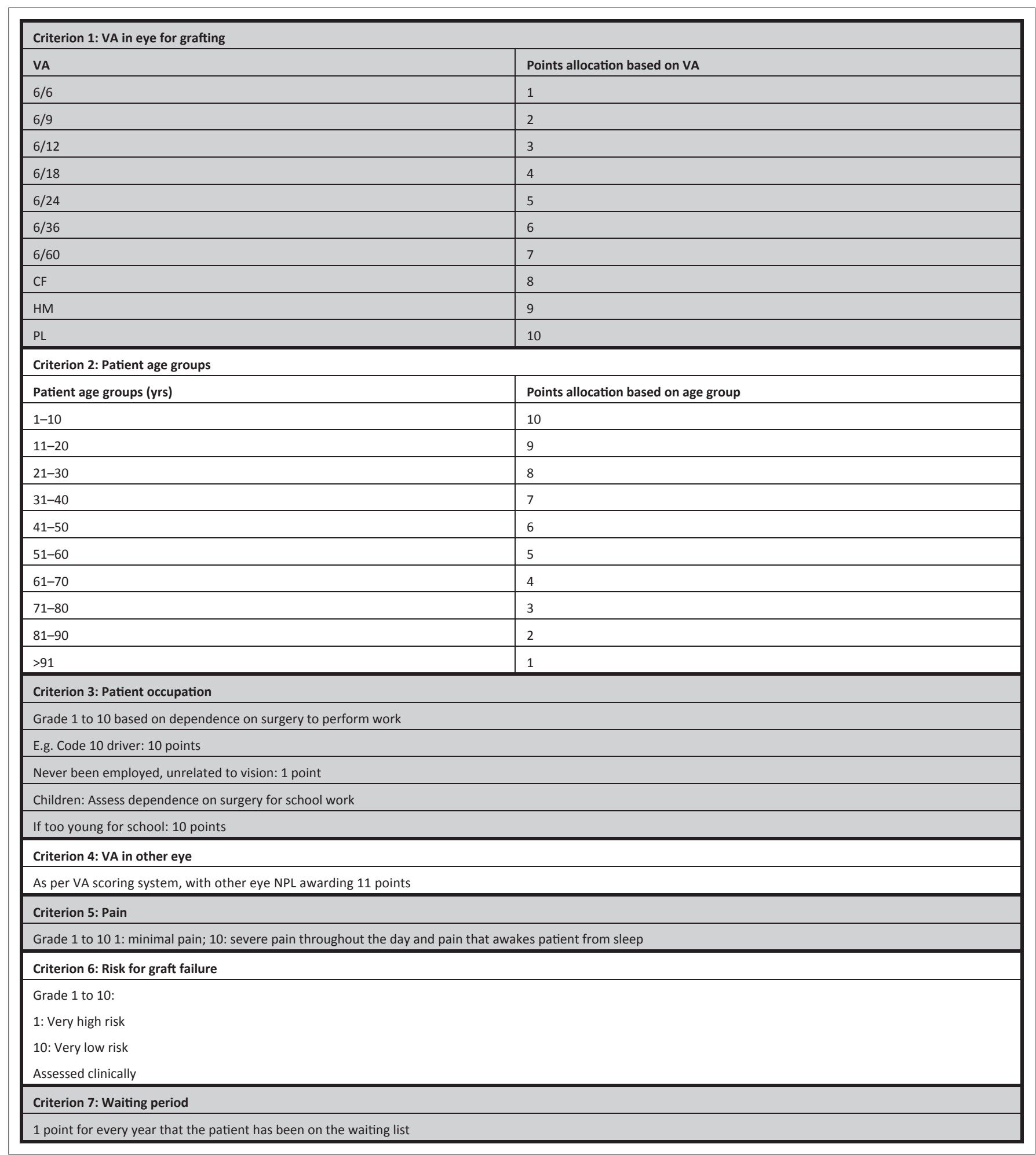

VA, visual acuity; CF, counting fingers; HM, hand movements; PL, perception of light; NPL, no perception of light. FIGURE 1: Corneal graft pro forma scoring system based on defined criterion.

donation, which means that organs of a deceased individual may not be donated without informed consent from the next of kin; this applies even when the individual is a registered organ donor. ${ }^{13,14}$

The corneal graft pro forma has assisted us in the prioritisation process. The main purpose is to help achieve a justified distribution of limited corneal tissue. Once a donor cornea becomes available, patients with 'higher scores' are contacted to come in for surgery. Of note is the fact that occasionally patients cannot be contacted, and in these cases the donor cornea goes to another patient on the waiting list.

A recommendation for the future is that additional points (instead of just 1) can be awarded to patients for every year that they have been on the waiting list. 
TABLE 1: Demographic and clinical profile of patients on the corneal graft waiting list in the eThekwini Health District, 2011-2014.

\begin{tabular}{|c|c|c|}
\hline Demographic and clinical profile of patients & Number of patients & $\%$ of patients \\
\hline \multicolumn{3}{|l|}{ Patient age groups (years) } \\
\hline $1-10$ & 2 & 2 \\
\hline $11-20$ & 20 & 19 \\
\hline $21-30$ & 28 & 27 \\
\hline $31-40$ & 20 & 19 \\
\hline $41-50$ & 13 & 12 \\
\hline $51-60$ & 5 & 5 \\
\hline $61-70$ & 10 & 10 \\
\hline $71-80$ & 4 & 4 \\
\hline$>80$ & 2 & 2 \\
\hline \multicolumn{3}{|l|}{ Gender } \\
\hline Male & 43 & 41 \\
\hline Female & 61 & 59 \\
\hline \multicolumn{3}{|l|}{ Race } \\
\hline Black & 67 & 64 \\
\hline Indian & 33 & 32 \\
\hline White & 4 & 4 \\
\hline \multicolumn{3}{|l|}{ Indications for corneal graft } \\
\hline Keratoconus & 67 & 64 \\
\hline Corneal dystrophies & 11 & 10 \\
\hline Pseudophakic bullous keratopathy & 6 & 6 \\
\hline Failed grafts & 3 & 3 \\
\hline Scarring from previous infection & 9 & 9 \\
\hline Scarring from previous trauma & 3 & 3 \\
\hline Scarring (unspecified) & 5 & 5 \\
\hline
\end{tabular}

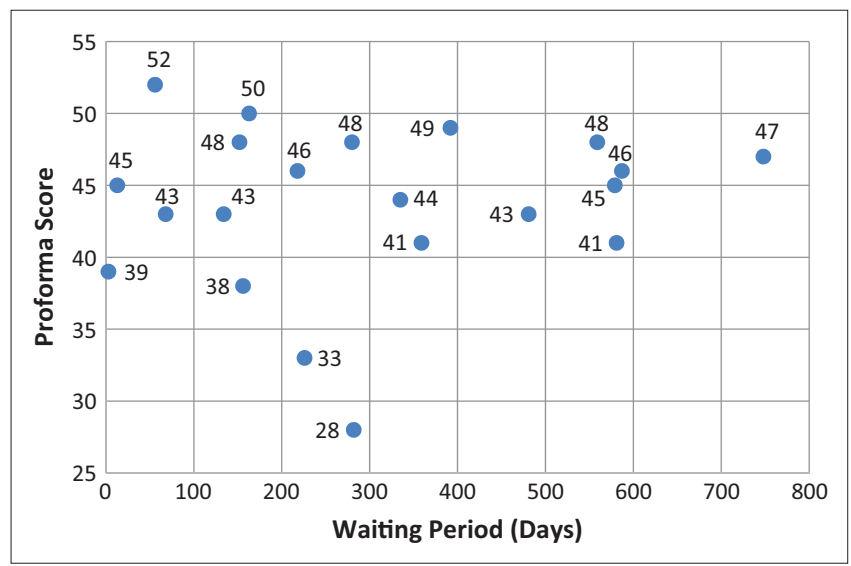

FIGURE 2: Scatter plot of waiting period and pro forma score of patients that received a corneal graft, eThekwini Health District, 2011-2014.

\section{Conclusion}

With a shortage of donor corneas, the time spent waiting for transplantation can be indefinite. Educational programmes targeting both healthcare workers and the public are vital to increase awareness of corneal blindness and the value of corneal donations. In the meantime we will continue to justifiably and objectively triage prospective corneal graft recipients, in order for the few grafts that are available to be distributed fairly and used most beneficially.

\section{Acknowledgements}

The advice from Dr S. Ballim and statistical support from Mr M.A. Khan is gratefully acknowledged.

\section{Competing interests}

The authors declare that they have no financial or personal relationships which may have inappropriately influenced them in writing this article.

\section{Authors' contributions}

M.K. (University of KwaZulu-Natal) was principal investigator in this study and was responsible for conceptualisation of the study, acquisition and analysis of the data, and writing of the manuscript. L.V. (University of KwaZulu-Natal) and S.M. (University of KwaZulu-Natal) reviewed and edited the manuscript. All authors read and approved the final version of the manuscript.

\section{References}

1. Whitcher JP, Srinivasan M, Upadhyay MP. Corneal blindness: a global perspective. Bull World Health Organ 2001;79(3):214-221.

2. Pascolini D, MariottiSP. Global estimates of visual impairment 2010. BrJ Ophthalmo 2012;96(5):614-618. http://dx.doi.org/10.1136/bjophthalmol-2011-300539

3. Resnikoff S, Pascolini D, Etya'ale $D$, et al. Global data on visual impairment in the year 2002. Bull World Health Org 2004;82(11):844-851.

4. Dandona R, Dandona L. Corneal blindness in a southern Indian population: need for health promotion strategies. Br J Ophthalmol 2003;87(2):133-141. http:// dx.doi.org/10.1136/bjo.87.2.133

5. Oliva MS, Schottman T, Gulati M. Turning the tide of corneal blindness. Indian Ophthalmol 2012;60(5):423-427. http://dx.doi.org/10.4103/0301-4738.100540

6. Rao GN. What is eye banking? Indian J Ophthalmol 1996;44(1):1-2.

7. Garg P, Krishna PV, Stratis AK, Gopinathan U. The value of corneal transplantation in reducing blindness. Eye 2005;19(10):1106-1114. http://dx.doi.org/10.1038/ sj.eye. 6701968

8. Burton MJ. Corneal blindness: prevention, treatment and rehabilitation. Comm Eye Health J 2009;22(71):33-35. [PMCID: 2823104]

9. Smith AF, Smith JG. The economic burden of global blindness: a price too high! Br J Ophthalmol 1996;80(4):276-277. http://dx.doi.org/10.1136/bjo.80.4.276

10. Pariyakanok L, Erjongmanee S, Saonanon P. Indications for corneal transplantation in Thailand between 1996 and 2008. Asian Biomed 2011; 5(6):843-848.

11. Makgotloe AZ. Gauteng cornea and eye bank registry: a report on corneal grafts done between January 1998 and December 2005. Johannesburg: University of the Witwatersrand; 2009. Available from: http://hdl.handle.net/10539/7999

12. Rao GN, Gopinathan U. Eye banking: an introduction. Comm Eye Health J 2009; 22(71):46-47. PMCID: 2823111.

13. Etheredge HR, Turner RE, Kahn D. Attitudes to organ donation among some urban South African populations remain unchanged: a cross-sectional study (1993-2013). S Afr Med J 2014;104(2):133-137. http://dx.doi.org/10.7196/ samj.7519

14. Organ Donor Foundation of South Africa. Statistics, How we create public awareness; Transplant centres in South Africa; How do I become a potential organ/tissue donor? 2015 [cited 2015 Jan 3]. Available from: http://www. odf.org.za 